\title{
The Aramaic Language and Pentateuch Verses Through the Perspective of the Aramaic Translation Targum Onqelos*
}

\begin{abstract}
Uri Zur
Ariel University, Ariel, Israel

Targum Onqelos is the translation of the Pentateuch (Torah) in Aramaic. According to the Babylonian Talmud (Megila 3a), this translation is attributed to Onqelos the Convert. According to research, however, the identity, time, and place of the translation are not definite. Targum Onqelos is a literal-semantic translation of the majority of Pentateuch verses, closely adhering to the Hebrew text without deviations, additions, or omissions. In this paper, the author will discuss Pentateuch verses for which the Targum Onqelos deviates from the typical literal mode of translation. These deviations can be classified into three types: (1) translation of anthropomorphisms, (2) the legal verses, and (3) translation of special speeches or poetry.
\end{abstract}

Keywords: Aramaic language, Aramaic translation, Targum Onqelos, Pentateuch verses

\section{Introduction}

Aramaic is an ancient Semitic language; for an extended period of time it served as the colloquial medium and was also recognized as a respectable means of formal communication throughout Mesopotamia, Babylon, and the nearby lands. At a certain point, Aramaic superseded Hebrew, which had been the spoken tongue of Jews living in the Land of Israel. In a number of instances, Aramaic even made its way into the text of the Hebrew Bible.

The Aramaic language developed gradually over time, branching out into a number of different forms during different eras in the various areas where it was in use. This was how the need arose for a translation of the Pentateuch into the contemporary lingua franca comprehensible to all the Jews then living in the Land of Israel. The translation associated with the name of Onkelos came to be accepted as an authoritative rendition of the text of the Pentateuch into Aramaic.

The translation commonly referred to as simply "Onkelos" for short, renders the Hebrew Biblical verses in Aramaic, most of the time observing a semantic-literal fidelity to the original text. Occasionally, however, the translator strays from this systematic approach. In the present paper, the author sets out to identify the distinct types of deviation to be found in the translation known as Onkelos, introducing a selection of examples to illustrate these different types.

\footnotetext{
${ }^{*}$ Published with the permission of Cambridge Scholars Publishing. Uri Zur, senior lecturer, Ph.D., Moreshet Israel Department, Ariel University.
} 


\section{Aramaic as an Ancient Semitic Language of Asia}

Aramaic has a very early origin, and its name is based on the Aramaean tribes in Syria (Komlosh, 1973, p. 14), although the use of this Semitic language became widespread in the 10th century BC, when Aramaeans settled in Mesopotamia, Babylonia, and Syria, in an area extending to the Canaanite border. Gradually, Aramaic became the lingua franca replacing Hebrew (Komlosh, 1973, p. 15; Rappel, 1985, p. 7) in everyday life and in the intellectual life of the Jews in the Mesopotamia region, in Syria and Israel in the following centuries. Aramaic was also used as the language of diplomacy, which is implied from Kings II 18:26 and Isaiah 36:11, when the servants of King Hezekiah ask Rabshakeh, emissary of the King of Assyria, to speak to them in Aramaic (Kutscher, 1977, p. 306).

Aramaic is a northern Semitic language with many dialects, a development that stems from differences of time and place. Aramaic and Hebrew are considered related Semitic languages and Aramaic has had significant influence on Hebrew (Encyclopaedia Biblica, 1965, pp. 593-595; Encyclopaedia Hebraica, 1953, V, pp. 961, 963, 966, 968-969). ${ }^{1}$ They are similar in syntax, grammar, vocabulary, and vowels and consonants, but differ in their phonology and structure. ${ }^{2}$

Aramaic served as an international language for all countries of the East from the eighth century BC until the reign of Alexander the Great (Encyclopaedia Hebraica, 1953, V, p. 952), and as the administrative language of the Persian Empire (Komlosh, 1973, p. 15). Between the fifth and seventh centuries BC, ${ }^{3}$ Aramaic functioned as the lingua franca connecting people in Central Asia and the Middle East (Encyclopaedia Judaica, 1973, pp. 260, 266).

\section{Aramaic in the Bible}

The first occurrence of Aramaic in the Bible is in a speech by Laban the Aramaean, who uses two Aramaic words " Bible, for example, Jer. 10:11, while other sections were influenced by Aramaic, such as verses from the story of Bilam (Num. 23:8), Proverbs (31:2), prophecies in the Book of Ezekiel (16:33). ${ }^{4}$ Translations of the Bible such as the Psuedo-Yonathan ben Uziel translation, the Yerushalmi translation, and the Onqelos translation, were written in Aramaic. Other documentation in Aramaic has also been discovered, including the Bar Kokhba letters, and the Elephantine documents. Finally, a large portion of the legalistic Rabbinical literature was written in Aramaic, including collections of legends (midrashei aggadah), and the Babylonian and Jerusalem Talmuds.

\section{Development of Aramaic}

Aramaic can be divided into five types (Kutscher, 1972, p. 4; Qimron, 1993, pp. 1-3): ${ }^{5}$

(1) Ancient Aramaic (925 BC-700 BC). Several inscriptions in ancient Aramaic have been found in various

\footnotetext{
${ }^{1}$ See Encyclopaedia Judaica (1973, pp. 282-283) on the influence of Aramaic on Hebrew of the Mishna and contemporary vernacular Hebrew.

${ }^{2}$ See (Kutscher, 1977, pp. 90-155) on the Aramaic language; see Encyclopaedia Judaica (1973, pp. 263-264) on features of Hebrew, Aramaic, and Arabic; and see Encyclopaedia Judaica (1973, pp. 266-267) on the impact of Aramaic on Biblical Hebrew. ${ }^{3}$ Until the mid-11th century, according to Epstein (1960, p. 16).

${ }^{4}$ See Encyclopaedia Judaica (1973, p. 267) notes additional biblical passages that were influenced by Aramaic.

${ }^{5}$ Encyclopaedia Judaica (1973, pp. 259-283) lists all types of Aramaic dialects and languages.
} 
archaeological excavations, especially in Syria, Mesopotamia, and Egypt (the Elephantine Documents). Early letters from the ninth century BC (Epstein, 1960, pp. 9-10) were found in Assyria, Aram-Naharaim, and Syria.

(2) Official Aramaic (700 BC-200 BC). This is known as the language used to draft official documents, deeds, or inscribe weights in Assyria and Persia (Epstein, 1960, pp. 9-10), contracts, seals, etc. (Encyclopaedia Judaica, 1973, p. 261), and in Persia it was also used as the official language and language of diplomacy (Encyclopaedia Judaica, 1973, p. 261). Examples of this type of Aramaic also appear in the Bible, for example in the Books of Daniel (2:4-7:28) and Ezra (4:8-6:18, 7:12-7:26).

(3) Middle Aramaic (200 BC-200 AD). The Onqelos Translation of the Bible was apparently written in this form in Israel and transmitted to Babylonia. ${ }^{6}$ This form has also been found in numerous texts, scrolls, and inscriptions (Encyclopaedia Judaica, 1973, pp. 267-269).

(4) Late Aramaic (200 AD-700 AD). Late Aramaic is divided into Eastern and Western Aramaic. The Babylonian Talmud, for example, was written in the Babylonian-Aramaic dialect of Eastern Aramaic, whose additional dialects include Syriac and Mandaic (Epstein, 1960, p. 13). The Jerusalem Talmud was written in the Aramaic-Galilean dialect of Western Aramaic, whose additional dialects include Samaritan Aramaic and Christian Aramaic (or Syriac-Israeli Aramaic) (Kutscher, 1977, pp. 169-175; Sokoloff, 2002, p. 3).

(5) Modern Aramaic (700 AD to the present) is spoken to this day in various parts of Asia. For example, the Ma'alula dialect is named after the village in the vicinity of Damascus where the dialect is spoken, as it is in two adjacent villages (Encyclopaedia Hebraica, 1953, V, p. 959). Various dialects of Aramaic are still spoken today in certain regions in Iraq, Iran, Turkey, several former Soviet republics, Kurdistan, and Syria.

\section{An Introduction to Onqelos and His Translation}

Targum Onqelos is the translation of the Pentateuch (Torah) in Aramaic. According to research, the identity, time, and place of the translation are not definite, but according to the Babylonian Talmud (bMegila 3a), this translation is attributed to Onqelos the Convert (or Akylas), a nephew of the Roman Emperor Hadrian (or Titus) who converted to Judaism in the early second century AD. Researchers are divided on whether Onqelos' translation of the Pentateuch into Aramaic and Akylas' translation of the Bible into Greek were written by the same person or two different people.

While the majority of scholars believe that these translations were made by two different individuals, a minority claims that a single individual was responsible for both translations. Possible dates of this work range from the first century AD to the fifth century AD, yet most scholars believe that the Targum was written in the third century $\mathrm{AD}$, based on an earlier foundation. The translation was written in Israel, and translated into Aramaic "[transcribed] from R. Eliezer and R. Yehoshua" (bMegila 3a), that is, under their supervision. Translation of the Pentateuch into Aramaic was intended to enable Diaspora Jews to understand the Pentateuch in their spoken language.

Targum Onqelos is a literal-semantic translation of the majority of Pentateuch verses, which generally adheres closely to the Hebrew text without deviations, additions, or omissions. The term "Targum Onqelos" first appears in the works of the Geonim (seventh to tenth century AD) and thereafter appears in medieval writings.

\footnotetext{
${ }^{6}$ Encyclopaedia Judaica (1973, p. 267) and Epstein (1960, p. 14) discuss the development of Targum Onqelos.
} 


\section{Targum Onqelos Features Three Main Types of Deviations From the Biblical Source}

In this chapter, the author discusses Onqelos' translations that deviate from his typical literal mode of translation. These deviations can be classified into three categories: (1) translations of anthropomorphisms, (2) legalistic verses, and (3) translations of special speeches or poetry.

\section{Translation of Anthropomorphisms}

The first category is the translation of anthropomorphisms, in which Targum Onqelos renders his translation in a non-literal way to avoid describing God in human terms. The following five examples are illustrative of this category.

The first example is from Genesis. In the story of the Tower of Babel (Gen. 11:5), the text reads " וירד ה' "לראות את העיר ואת המגדל אשר בנו בני האדם ("And the LORD came down to see the city and the tower, which the children of men built"). Onqelos' translation for this verse reads as follows: We itgali G-d al ovad karta umigdla dibno bnei anasha, meaning: The LORD was revealed on the actions of the city and the tower that the people had built. The verbs "come down" and "see" in the original verse were not translated by Onqelos, to avoid anthropomorphism.

The second example is from the story of the Garden of Eden. When the snake persuades Eve to eat from the Tree of Knowledge of Good and Evil, he rationalizes God's reason for the prohibition in Gen. 3:5: "כיודע אלוקים כ" "for God doth know that in the day ye eat thereof, then your eyes shall be opened, and ye shall be as God, knowing good and evil"). In Targum Onqelos, this is translated as "ארי גלי קדם ה". The word "know" is not translated literally into its corresponding Aramaic term "למידע". Onqelos modifies this, by adding the phrase "גלוי לפני קרפ" ("disclosed before [God]"), to prevent Aramaic readers from believing that God possesses knowledge that is similar to man. For this reason, Onqelos offers a translation that is interpretative and abstract. Onqelos writes: It is known and disclosed to God that if they eat from the fruit of the tree, they will understand the difference between good and evil.

Merely for sake of comparison, Rashi, who does not follow Onqelos' translation, offers a literal interpretation of this verse. According to Rashi, this verse means: You will be able to create worlds, and God does not wish you to become similar to him.

The third example is taken from a scene described immediately after the sin of eating of the fruit of the Tree of Knowledge in Gen. 3:8: "'וישמעו את קול ה' אלוקים מתהלך בגן" (And they heard the voice of the LORD God

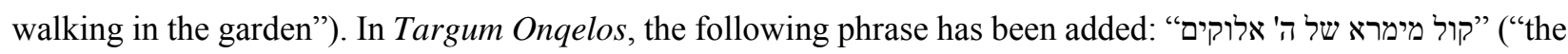
words of God"). Onqelos added the word "מימרא" which means [God]'s "words", to stress that what Adam and Eve heard in the Garden of Eden were God's words, rather than God's voice. In his Aramaic translation, Onqelos wished to prevent any misunderstanding of the verse by emphasizing that God is no mortal who has a voice or generates sounds in a manner similar to human beings. Again, for the sake of comparison, Rashi's literal interpretation of the verse is: They heard God's voice in the Garden.

The fourth example is from the account of how God informs Abraham of his desire to punish the inhabitants of Sdom and Amorah, who Abraham then attempts to defend. In Gen. 18:22 it says: "ואברהם עודנו עומד לפני ה'"

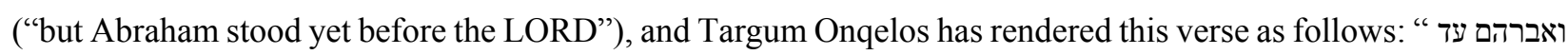
"כען משמש בצלו קדם ה', which means "Abraham is still praying to God". According to Rashi, the text of this verse 
contains a scribal emendation, and should be read: "As God was still standing before Abraham".

In his volume on Targum Onqelos, Komlosh (1973, p. 170) stated that even after the scribal emendation, this verse, "'ואברהם עודנו עומד לפני ה" ("but Abraham stood yet before the LORD”) is considered inappropriate with regards to God. Onqelos, who undoubtedly shared this view, sought to convey that it is impossible for any human, including Abraham, to physically stand before God. The only possibility that seemed feasible to the translator, also in order to prevent anthropomorphism, was to interpret the word "stand" ("עמוד") as "praying" [Tafsir, (= a translation of the Pentateuch into Arabic by the late ninth century sage R. Saradya Gaon) ad loc.]. Indeed, an individual in prayer may be seated or standing. The latter is exemplified in the Shmoneh-Esre prayer also known as Amida, which means "standing".

The fifth example illustrating this category is taken from the story of Noah and the Flood, when Noah

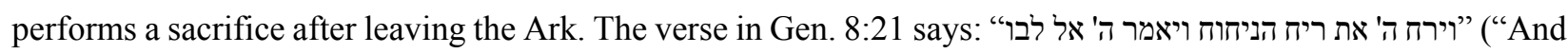

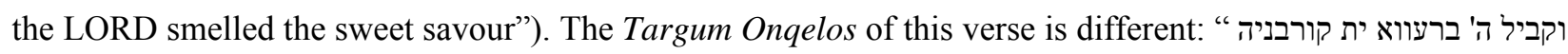
ואמר ה' במימריה Allo the verbs typically used to describe human action—to see, smell, say—were translated into Aramaic in a manner that not only prevents any risk of anthropomorphism, but also rendered them into vernacular terms. For example, the phrase "וירח ה' את ריח הניחוח" (“And the LORD smelled the sweet savour”) was rendered in translation as "God willingly accepted [Noah's] sacrifice".

The second half of the verse "and the LORD said in His heart" was rendered as "God said in his words". The Tafsir (ad loc.) follows Onqelos' version to prevent anthropomorphism, as does the commentary by R. Abraham Ibn Ezra (early 11th century). According to R. Abraham Ibn Ezra, it is inappropriate to say that "God smells". He explains that this verb actually means that God accepted and was pleased by the sacrifice, like a person is pleased when he smells a fragrant smell, “"וחלילה חלילה להיות ה' מריח... והוא מבאר: רק הטעם [ה'] שקיבל את הקרבן וישרה לפניו כ"כאדם שמריח ריח טוב והוא ערב

These are only a small number of the examples from this category in which biblical verses were translated differently from their original to prevent anthropomorphism and to enhance readers' comprehension. To achieve these goals, Onqelos makes use of several linguistic devices in Aramaic concerning God's name. He uses the words: God's divine presence, God's honor, fear of God, before God, God's words, to substitute for "God" in the text.

Furthermore, Komlosh (1973, pp. 106-116) distinguishes between Onqelos' differentiated uses of these terms. For example, "God's divine presence" appears when Onqelos wishes to note that spirit of God in the Temple or with the People of Israel; and "fear of God" is used in the context of a person who follows God's commandments.

Despite Onqelos' desire to avoid anthropomorphism, we observe that Onqelos translated a number of verses ויברא א' את " : 1:27 "האדם בצלם א' ברא אותו ("And God created man in His own image") was translated literally into Aramaic, as was the verse in Deut. 9:10: "' "' "'the LORD gave me the two tables of stone, even the tables of the covenant"). One explanation for these exceptions is that in these verses Onqelos relies on the readers to reject a literal understanding of the verse because the use of anthropomorphism is so blatantly far from reality. 


\section{Legalistic Verses}

The second category of verses that was treated uniquely by Onqelos comprises verses of a legalistic nature. In these verses, for various reasons, Targum Onqelos intended to emphasize a specific law (Halacha), as the following five examples illustrate.

The first example reflects an approach opposing those who believe exclusively in the written Torah and do not believe in the Oral Torah that was handed down through the traditions of the Sages. Lev. 23:11: "ממחרת השבת" ("on the morrow after the Sabbath") was translated by Onqelos as "Mibatar yama tava", meaning from the day after a holiday (bMenahot 65b). The implication of this translation is that the Omer, which means 49 days between the second day of Passover and Pentacost, should be counted from the second day of Passover. The Targum Onqelos does not contain the word "Sabbath" which appears in the original Torah text - to emphasize that the Omer should not be counted from the day after the first Sabbath following Passover, as was customary for various sects that did not believe in the Sages' Oral Law.

לא תבשל גדי " : ל : The second example, designed to emphasize an early or customary legal tradition is Ex. 23:19 "בחלב אמו "(Thou shalt not seethe a kid in its mother's milk"). Onqelos translated this verse as: Lo teichalun bassar ba halav, meaning "do not eat meat with milk". The prohibition to eat meat and milk together is the halachic tradition of this verse, rather than its literal meaning, not to cook a kid together with its mother's milk. Although there are three related halachic prohibitions involving meat and milk (cooking, enjoying, eating, according bHullin 115b), Onqelos consistently chooses the prohibition of eating as the translation for the three times this phrase is mentioned in Exodus (Ex. 34:26, 23:19).

Several of the modifications of legal rules in Targum Onqelos were designed to emphasize the conventional behavior associated with biblical commandments. Our third example is based on the daily commandment to wear phylacteries (Tefillin) above the forehead during Shacharit morning prayers. According to Ex. 13:16: " " ("בין עיניך " "לטוטפון "and for frontlets between thine eyes"). Onqelos might have used the Aramaic word appears in Targum Yonathan ben Uziel (an Aramaic translation of Prophets and Writings of the Bible): "טוטפתך " "יהון עלך "פארך חבוש עליך" ("bind thy headtire upon thee"). Instead, Onqelos' translation for the verse in Exodus is "וללתפילין בין עינך" ("And the Tefillin between your eyes”), referring to the well-known and commonly practiced commandment of Tefillin that was placed on the forehead. Rashi follows this interpretation and notes the etymology of the Hebrew word "לטוטפות", which appears in the Babylonian Talmud (bSanhedrin 4b).

Another example of Onqelos' translation for a verse based on a known and commonly performed commandment involves the commandment of the Four Species related to the Feast of Tabernacles. According to Lev. 23:40, "And ye shall take you on the first day the fruit of goodly trees, branches of palm-trees, and boughs of thick trees, and willows of the brook"). Targum Onqelos contains no mention of the words "fruit of goodly trees", "branches of palm-trees", or "boughs of thick trees". Instead, these are translated according to the well-known interpretation of the Sages for this commandment, in an oral tradition: The goodly tree is identified as an Etrog, the palm trees are a Lulav, and the thick trees are the Myrtle (bSukka 32a-b, 33b, 35a). In his translation, the Tafsir, R. Saradya Gaon followed Onqelos and applied the common interpretation of the commandment in his translation of the names of the four species into Arabic. 
The final example of this category comprises two brief examples relating to law and justice. The first is based on Gen. 9:6: "שופך זם האדם באדם זמו ישפך" ("Whoso sheddeth man's blood, by man shall his blood be shed”). Onqelos translated the phrase "באדם דמו ישפך" ("by man shall his blood be shed") into Aramaic according to Jewish law: "בסהדין מיממר דייניא דמיה יתאשד" ("According to the judges, he will be sentence to death, according to witnesses"). In other words, a murderer will be sentenced to death only if there are witnesses to the act, and the judges so decide. This law appears as early as the Tannaim's collection of laws (Sifri, Num. parg. 160).

The second example is taken from Ex. 23:7: "'וניקי וצדיק אל תהרוג" ("and the innocent and righteous slay thou not"). Onqelos did not translate the term "Zadik" literally, but rather in accordance with the oral tradition of the Sages ("Whoever is found innocent in court, is not put to death") (bSanhedrin 33b): " ("Whoever was found innocent in a court of law, is not returned to the court, even if someone says that he wishes to make a statement that undermines the verdict"). However, Onqelos does not always conform his translations to the oral traditions of the legal commandments, which were the accepted interpretations of those verses.

Occasionally he retains the original wording and renders a literal translation. As a result, his translation might be misunderstood by readers as representing an opinion opposing halacha. For example, the phrase "an eye for an eye" (Ex. 21:24, Lev. 24:20, Deut. 19:21) was translated literally by Onqelos ("עינא חלף עינא"): "Whoever injures his friend's eye, shall have his own eye injured by the friend in retaliation". This is not, however, the interpretation that the Sages ascribed to this phrase. According to the sages, "an eye for an eye" meant that the injured party should receive monetary damages not a retaliatory injury (bSanhedrin 84a).

The Karaites did not accept the Sages interpretation of this verse. They supported a literal interpretation of this legal rule, while the Sages believed that monetary compensation was required in the case of a physical injury. Although Onqelos might have been expected to render a translation according to the Sages tradition, his translation for this phrase is in fact a literal one.

All this leads us to state the following as a summary of this category. We have no way of knowing whether the translator had a principled approach that guided him in choosing whether to translate legal rules literally or according to the halacha. Based on the nature of Onqelos' translation, it seems that there was no special system or principle guiding him, and his decision was based on various considerations. One consideration was convenience and simplicity of the translation to ensure readers' comprehension. Another consideration was the desire to emphasize specific legal rulings in the face of opposing interpretations. Possibly, even Onqelos' own idiosyncrasies came into play.

\section{Special Speeches or Poetry}

The third category involves the translation of special speeches or poetry. In these cases, Onqelos expands on the translation by introducing additional information (in the form of glosses or a Midrash Aggadah, which is a collection of legends in classical rabbinic literature). This is shown in the following five examples.

The first example is taken from Jacob's blessing to his sons. Jacob's blessing to Naftali in Gen. 49:21 is נפתלי בארע טבא יתרמיה עדביה "'Naphtali is a hind let loose"). Onqelos translates this as ("נפתלי איילה שלוחה" (") ואחסנתיה תהי מעבדא פירין ("In good soil shall his destiny be planted, and his estate shall produce fruit”). Onqelos' translation is based on a collection of legends (Bereshit Rabbah 99:12) which notes the geographical location of Naftali's inheritance and its fertility: "This is the Genosar Valley which hastens as a deer to produce its fruit". 
Onqelos' translation of the blessing to Joseph (Gen. 49:24) "ותשב באיתן קשתו" ("But his bow abode firm") is ותבת " וs similarly based on a Midrash Aggadah, and is completely different from the source. Onqelos translation is "בהון נביותיה על דקיים אורייתא בסתרא meaning that Joseph's dreams were fulfilled through his brothers because he maintained the Torah in secret. His translation is based on R. Shimon Hassida in the Babylonian Talmud (bSota 10 b), "יוסף שקידש שם שמים בסתר" (Joseph sanctified God in secret).

Benjamin's blessing (Gen. 49:27) "בנימין זאב יטרף" ("Benjamin" is a wolf that raveneth") is translated by Onqelos as “"'God's spirit shall rest in Benjamin's estate, and the Temple shall be built in his portion”), according to the legend (Mechilta D`Rabbi Ismael, Ex. Beshelach parg. 5, p.105; Mekhilta D“ Rabbi Š im‘on b. Jochai, 14:22, p. 63), “שרתה השכינה בחלקו" (God's spirit rested in his estate) and the legend (Sifri, Deut. parg. 352): "מלמד שבית המקדש היה בנוי בחלקו של בנימין" which shows that the Temple was built on Benjamin's estate.

The second example involves two verses in the Song of the Sea. The first verse (Ex. 15:1): “ "ישיר משה ובני אי "'Then sang Moses and the children of Israel this song unto the LORD, and spoke, saying: I will sing unto the LORD, for He is highly exalted”) is translated by Onqelos as "נשבח ונודה לה' כי התגאה על גאים" (We will praise and thank God because he has more pride than those who are arrogant). The word "אשירה" ("I will sing") appears in the singular, but Onqelos translated it in the plural. This follows a legend of R. Akiva, who was quoted as saying, "This shows that the People of Israel would repeat in song after Moses" (bSota 27b). The translation of "כי התגאה על גאים" ("he has more pride than those who are

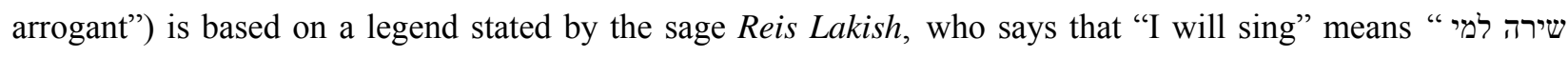
"שמתגאה על הגאים ("song to God, who he has more pride than those who are arrogant”) (bHagiga 13b). Rashi follows Onqelos' translation of this section of the verse.

The second verse from the Song of the Sea is "זה אלי ואנוהו" ("This is my God and I will glorify him") (Ex. 15:2). Targum Onqelos for this verse reads: Den Aloki ve evne leh makdash, meaning "This is my God and I will build him a temple", even though the original verse makes no mention of the building of a temple. The Targum adds the words/sentence "building of a temple" on the basis of a legend that apparently was known to Onqelos the translator (Shemot Rabbah 49:2). "זי" "This is my God and I will glorify him"), which means, I was in error in committing the sin of the Golden Calf, and I acted properly in building the Mishkan.

The third example is taken from two verses in Bilam's speech. In the first (Num. 24:17), "דרך כוכב מיעקב וקם "שבט מישראל "There shall step forth a star " out of Jacob, and a scepter shall rise out of Israel”), Onqelos renders an eschatological translation that refers to the Days of the Messiah ("מד יקום מלכא מיעקב, ויתרבא משיחא "מישראל -When a king from Jacob appears, and the Messiah will come from Israel). Onqelos is not alone. R. Akiva attributed this verse "there shall step forth a star out of Jacob" to Bar Kochva, leader of the Bar Kochva rebellion against Rome in 135 AD, whom R. Akiva considered to be the Messiah. The Midrash Lekah Tov (1960) also contains a legend that describes the Days of the Messiah and states "there shall step forth a star out of Jacob" (p. 258). In the Yerusalemi Talmud (Ned. 38a), R. Acha concluded from this verse that the Messiah will be from the House of Jacob. Although Rashi instructed to follow Targum Onqelos ("כתרגומו"), his own interpretation is

\footnotetext{
${ }^{7}$ See (Kutscher, 1977, pp. 322-323) on the origin of the name Benjamin - person of my oath, ally.

${ }^{8}$ See (Kutscher, 1977, pp. 331-333) on the interpretation of this verse.
} 
unrelated to the Onqelos version.

The second verse is from Bilam's speech (Num. 24:23) " אוי מי יחיה משומו אל"Alas, who shall live after God hath appointed him?"). Onqelos translated this as "Woe to the nations who live when God does all these things". Onqelos applied an eschatological interpretation to this verse as well, based on a legend on this verse that was also known to R. Yochannan: "אוי לה לאומה שתימצא בשעה שהקב'ה עושה פדיון לבניו" (bSanherin 106a) ("Woe to the nation that may be found [attempting to hinder], when the Holy One, blessed be He, accomplishes the redemption of his children").

The fourth example is taken from Moses' blessing to the nation before his death. Moses says (Deut. 33:2):

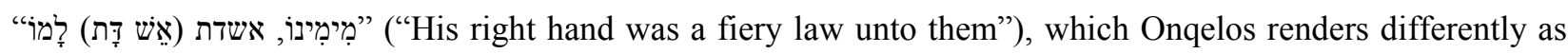
"כתב ימיניה מגו אישתא אורייתא יהב לנא", meaning that God wrote the Torah in fire with his right hand, and gave it to דברי תורה נמשלו לאש, מה אש " דerse Onqelos' translation is based on a legend (Sifri Num. parg. 343) to this vere דברי תiven from the heaven, so the words of the Torah were handed down from heaven. Onqelos' translation is identical in both the Targum Yerushalmi A and Targum Yerushalmi B; Rashi's interpretation follows Onqelos as a second interpretation for this verse, while R. Sa‘adya Gaon translates this verse into Arabic in a similar manner: “ אש מימינו, [ונתן] להם (Torah [is a] fire from His right hand, and He gave it to us).

The fifth example is also from the same chapter as above (Deut. 33:21), and refers to Moses' blessing to the tribe of Gad: "כרי שם חלקת ספון " "for there a portion of a ruler was reserved”), which Onqelos translates as "תמן באחסנתיה משה ספרא רבא דישראל קביר , because Moses, who is Israel's great author, is buried there, according to the legend (Sifri, Deut. parg. 355) that Moses was buried in Gad's territory. The legend also addresses the contradiction, because Moses apparently died while on Reuven's territory, on Mt. Nevo (Num. 32:49), and states: "He was transferred on the wings of God's spirit to Gad's territory". Rashi follows the Targum Onqelos, but R. Sa‘adya Gaon offers a slightly different interpretation in Arabic " (אן ג'ווקה אל רסמין הינאק מכנוזה" (because the flock of legislators is buried there), which implies that Moses, Miriam, and Aharon were all buried in the east bank of Jordan. Only R. Abraham Ibn Ezra gives a literal interpretation of the verse concerning the Tribe of Gad, who asked for land in the east bank of Jordan, before the Israelites entered Israel.

To sum up this category, Onqelos apparently viewed verses in this category as allegories whose morals he allows himself to interpret according to legends, to which he sometimes adds his own expansions of legends. Another possibility is, that since this type of verses is linguistically complex and difficult to translate into Aramaic, and difficult for readers' to understand, Onqelos avoids translation-related issues by relying on the meaning of the verses as they appear in legends.

\section{Conclusion}

Targum Onqelos is a literal-semantic translation of the majority of Pentateuch verses, which generally adheres closely to the Hebrew text without deviations, additions, or omissions. But sometimes Onqelos' translation is deviate from his typical literal mode of translation. These deviations can be classified into three categories: (1) translation of anthropomorphisms, (2) translation of legal verses, and (3) translation of special speeches or poetry. 


\section{References}

Ben Eliezer, S. (Ed.). (1960). Midrash Lekah Tov (Legend of good lesson). Jerusalem: Repr..

Encyclopaedia Biblica (3rd ed.). (1965). Jerusalem: Bialik Institute.

Encyclopaedia Hebraica. (1953). Jerusalem: Massada Press.

Encyclopaedia Judaica (2nd ed.). (1973). Jerusalem: Keter Publishing House.

Epstein, J. N. (1960). A grammar of Babylonian Aramaic. Jerusalem: Magnes Press.

Epstein, J. N. (Ed.). (1979). Mekhilta D`Rabbi Š im‘on b. Jochai (Legend of R. Sime’on bar Jochai). Jerusalem: Sumptibus Hillel Press.

Komlosh, Y. (1973). The Bible in light of the Aramaic translations. Tel-Aviv: Dvir Press.

Kutscher, E. Y. (1972). A history of Aramaic. Jerusalem: Magnes.

Kutscher, E. Y. (1977). Hebrew and Aramaic studies (Vol. I). Z. Ben-Hayyim, A. Dotan, \& G. Sarfatti (Eds.). Jerusalem: Academon Press.

Mirkin, M. A. (Ed.). (1958). Bereshit Rabbah (The great legend of genesis). Tel Aviv: Yavneh Publishing House.

Mirkin, M. A. (Ed.). (1960). Shemot Rabbah (The great legend of Exodus). Tel Aviv: Yavneh Publishing House.

Qimron, E. (1993). Biblical Aramaic. Jerusalem: Bialik Institute.

Rabin, I. (Ed.). (1960). Mechilta D`Rabbi Ismael (Legend of R. Ismael). Jerusalem: Bamberger \& Wahrman.

Rappel, D. (1985). Targum Onqelos KePerush LaTorah. Tel Aviv: Hakibbutz Hameuchad.

Shalom, M. E. (Ed.). (1948). Sifri (Legend of numbers \& deuteronomy). New York: Om Publishing Co. repr..

Sokoloff, M. (2002). A dictionary of Jewish Palestinian Aramaic of the Byzantine period. Ramat-Gan: Bar Ilan University Press. 